Journal of Nepal Geological Society, 2019, vol. 58 (Special Issue), pp. 1-12

DOI: https://doi.org/10.3126/jngs.v58i0.24568

\title{
Mitigation and Bioengineering Measures for Prevention of the Surbhi Resort Landslide, Mussoorie Hills, Uttarakhand Lesser Himalaya, India
}

\author{
*Vinod C. Tewari ${ }^{1}$ and Victoria Z. Bryanne ${ }^{2}$ \\ ${ }^{1}$ Geology Department, Sikkim Central University, Tadong, Gangtok- 737102, Sikkim, India \\ ${ }^{2}$ Mahadev Residency - III, Anand Vihar, Jakhan, Rajpur Road, Dehradun - 248001, Uttarakhand, India \\ *Corresponding author:vctewari@cus.ac.in
}

\begin{abstract}
Recent cloud bursts and Glacial Lake Outburst Flood ( GLOF ) in the Uttarakhand Himalaya have triggered catastrophic landslides. Heavy monsoon precipitation lashed Uttarakhand causing devastation and series of new landslides in the region. The Surbhi Resort Landslide is located near the hill station of Mussoorie in Garhwal Himalaya, India, in the Upper Krol Limestone. After intense rain in August 1998, the Krol sedimentary deposits suddenly gave way as a deep-seated landslide, blocking the main Mussoorie-Kempty artery for 15 days. In 2005, the velocity of the slide was determined to be $4-14 \mathrm{~mm}$ /year by previous workers, thus it was still active with a modest intensity. Recently in 2018, during monsoon there was heavy rainfall in the Mussoorie and mud flow in the Kemty Fall area. Huge amounts of quaternary debris are still lying on the slope, another high intensity rainfall or cloud burst in future could trigger another large-scale failure. Based on our recent detailed investigations, following mitigation and bioengineering measures are suggested. To lower the ground water table, a series of horizontal drains should be installed at the base of the crown portion of the slide. This would generate an additional discharge which has to be channeled down Rangaon-ka-Khala, the natural channel, down the slope to the Aglar River flowing in the valley below. To prevent further surface erosion, it is suggested that the Rangaon-ka-Khala must be bioengineered with shrubs and grasses such as Eriophorum comosum, Saccharum spontanum, Pogonatherum spp. and Woodfordia fruticosa while the surrounding slope must be reforested with Quercus leucotrichophora, Alnus napelensis, Pinus spp. and Cedrus spp. Check dams must be constructed on the entire $3.5 \mathrm{~km}$ stretch of the Rangaon-ka-khala to lower the velocity of the water. This could be done either as gabions or in the form of live fascines of Salix tetrasperma or Dalbergia sissoo. The catchment area above the Mussoorie-Kempty road can be expected to collect $60,000 \mathrm{~m}^{3}$ in 24 hours in a 25 -years reoccurrence cloud burst. Thus proper drains $(0.40 \mathrm{~m}$ in dia.) on the inside of the road must be installed. The flow velocity at these extreme events would be $4.8 \mathrm{~m} / \mathrm{s}$, which is slightly above the recommended value. If this water is allowed to flow down the Rangaon-ka-Khala it will most certainly lead to a major debris slide with a vertical velocity of almost $100 \mathrm{~m} / \mathrm{s}$ with huge erosive power. For this reason, this discharge should be channeled down in plastic or cement lined pipes, preferably to the west of the Siyagaon Village which is reported as stable rather than in the landslide zone itself. It is concluded that these mitigation measures and bioengineering plantation would certainly help stabilize the Surbhi landslide area to prevent further disaster in future that destroyed the water mills, fields of the surrounding villages and mud flow in popular Kempty Fall area. These measures may also be applicable for the other active landslide zones in the NW (Jammu and Kashmir) and NE ( Darjiling-Sikkim ) Himalaya.
\end{abstract}

Keywords: Mussoorie, Lesser Himalaya, Uttarakhand, India, Mitigation, Bioengineering

Paper Received: 16 Feb 2018

Paper Accepted: 6 May 2018

\section{INTRODUCTION}

The Himalayas are getting warmer at a rate of $0.6^{\circ} \mathrm{C}$ each decade, three times the global average. Rainfall is increasing at a rate of $65 \mathrm{~mm}$ per decade, but skewed leading to the monsoon season getting wetter, while the winters are getting drier (Tewari, 2013). This is especially worrisome when considering natural disasters like landslides, the retreat of glaciers, GLOF and draughts. The Kedarnath disaster of 2013 in Uttarakhand due to GLOF is also described as Himalayan or mountain tsunami (Tewari, 2013a, b, 2014). This disaster now warns us to look the entire Himalaya from Jammu and Kashmir in NW to Sikkim in NE region, since such events may occur in the future where majority of high-altitude lakes are situated.
Majority of landslides in the Himalayas are rain triggered (Tewari, 2013, 2014; Bryanne and Tewari, 2014; Gupta et al., 2016). Shallow landslides tend to be sensitive to sudden cloudbursts and short duration, high intensity rainfall, while deep seated landslides tend to react to long antecedent rainfall spanning over 10 to 20 days. Recent cloud bursts and Glacial Lake Outburst Flood (GLOF) in the Uttarakhand Himalaya have triggered catastrophic landslides. Heavy monsoon precipitation lashed Uttarakhand causing devastation and a series of new landslides in the region. Surbhi Resort Landslide is located near the hill station of Mussoorie in the Garhwal Himalaya, Uttarakhand in the Upper Krol C Limestone. After intense rain in August 1998, the Krol sedimentary deposits 
suddenly gave way as a deep-seated landslide, blocking the main Mussoorie-Kempty artery for 15 days. In 2005, the velocity of the slide was determined to be $4-14 \mathrm{~mm} /$ year by previous workers, thus still active with a modest intensity. However, since huge amounts of quaternary debris are still lying on the slope, another high intensity rainfall or cloud burst could trigger another large-scale failure. Recently, various geotechnical studies and geological modeling of the rocks have been done and soil samples from the Surbhi landslide zone have shown inherent instability of the slide and its vulnerability to increased pore water pressure. Hence its mitigation measures are focused on lowering the ground water table using horizontal drains at the row of the slide zone and installing proper road drains along the Mussoorie-Kempty road. This would generate an additional discharge, which has to be channeled down the Rangaon-kaKhala, the natural channel, down the slope to the Aglar River flowing in the valley below. To prevent further surface erosion, the Rangaon-ka-Khala must be bioengineered with shrubs and grasses such as Cymbopogon nardis, Eriophorum comosum, Saccharum spontanum, Pogonatherum spp. and Woodfordia fruticosa while the surrounding slope must be reforested with Quercus leucotrichophora, Alnus napelensis, Pinus spp. and Cedrus spp. Check dams must be constructed on the entire 3.5 $\mathrm{km}$ stretch of the Rangaon-ka-Khala to lower the velocity of the water. This could be done either as gabions or in the form of live fascines of Salix tetrasperma or Dalbergia sissoo. Further, in the absence of mitigation measures, it is suggested that an early warning system should be set in place based on the intensity and antecedent rainfall in the area. It is suggested that these mitigation measures and bioengineering plantation would certainly help stabilize the Surbhi landslide area to prevent future disasters and that a warning message could be send to limit the impact. These measures may also be applicable for the other active landslide zones in the NW (Jammu and Kashmir) and NE (Darjeeling-Sikkim) Himalaya.
The Surbhi Resort Landslide is located near the hill station of Mussoorie in the Garhwal Himalaya (Fig. 1) in the Krol C limestone. After intense rain in August 1998, the slope suddenly caved in as a deep-seated landslide, blocking the main Mussoorie-Kempty artery for 15 days. Following this incident, the landslide has been extensively studied by several authors. Revised Neoproterozoic stratigraphy and sedimentological studies of the Krol Formation has been given by Tewari (2010, 2012) and Tewari and Tucker (2011). The present work follows location and drainage map by Khanduri (2017) for the Mussoorie area, Uttarakhand (Fig. 2). The geotechnical strength parameters were studied by Gupta and Ahmed (2007). Pal et al. (2010) tried a distinct element stability analysis while Singh et al. (2015) applied both static and dynamic analyses to the slope. All these studies reached the same conclusion that the slope is inherently unstable due to a wedge formation in the crown portion which is accentuated when the pore water pressure increases during monsoon. Venkateswarlu and Tewari (2014), Bryanne and Tewari (2014), Singh et al. (2015) and Gupta et a. (2016) have used different models for failure analysis. Present study focuses on the geological and petrological aspects of the failure zone, i.e. Krol Formation, together with mitigation and bioengineering measures of the landslide based on previous work by the present authors. The possibilities of developing an Early Warning System for future mass wasting processes on a local and regional scale is discussed and suggested.

\section{STUDY AREA}

The Surbhi Resort Landslide is located between longitudes $70^{\circ} 02^{\prime}$ and $78^{\circ} 04^{\prime} \mathrm{E}$ and latitudes $30^{\circ} 28^{\prime}$ and $30^{\circ} 31^{\prime} \mathrm{N}$ in the Dehradun and Tehri districts of Uttarakhand between the 6th and 7th kilometer stones from Mussoorie on the MussoorieKempty Road. The area is criss-crossed by four major joint sets trending in NE-SW, NNE-SSW, NNW-SSE and ESE-WSW
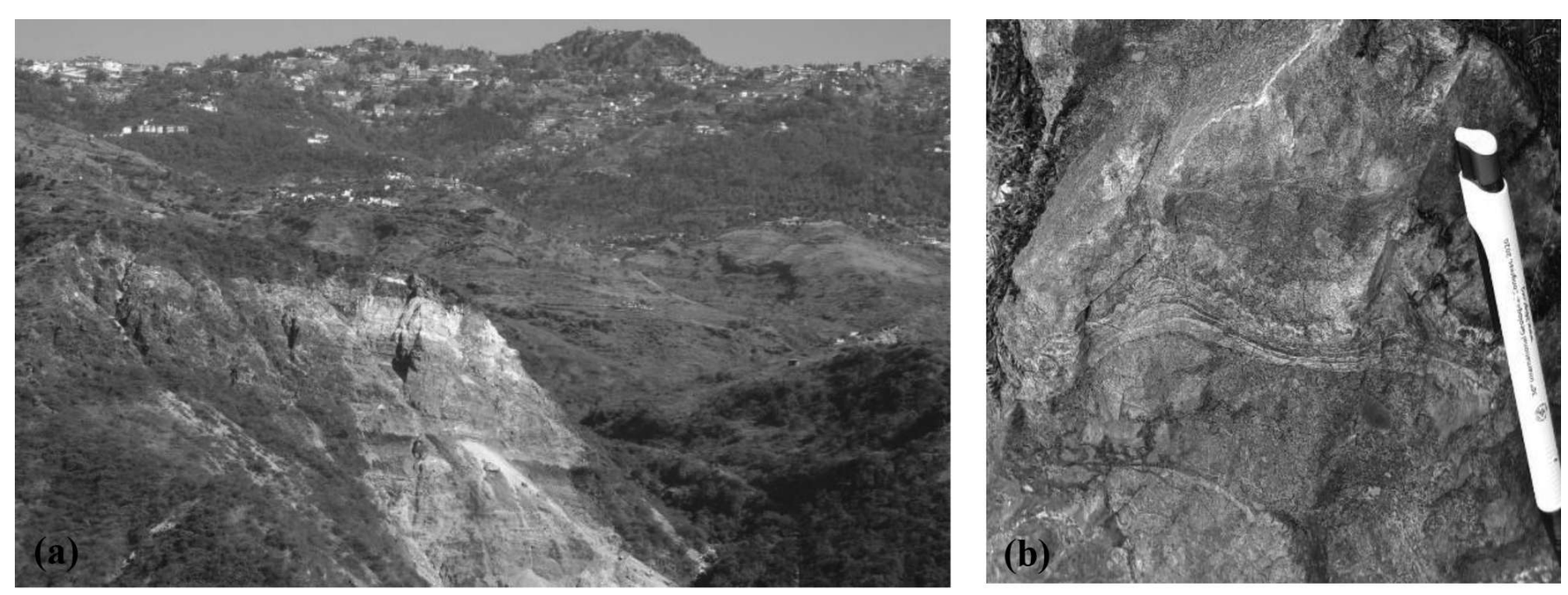

Fig. 1: (a) Panoramic view of Mussoorie Syncline showing bluish grey Upper Krol C Limestone; Mussoorie town is situated on Krol D at the top of the hill, and (b) Cherty intraclastic stromatolites. 
directions. (Gupta and Ahmed, 2007) The Surbhi Resort Landslide is located in the Krol Formation around the Mussoorie Syncline, Uttarakhand Lesser Himalaya. (Fig. 2).

\section{Upper Krol Formation}

The Upper Krol Formation is a typical Ediacaran (Terminal Neoproterozoic) microbial carbonate sedimentation facies. It is well developed in the Lesser Himalayan Krol belt extending from Solan in Himachal Pradesh to Nainital in the Uttarakhand Lesser Himalaya. The Upper Krol Formation contains Ediacaran metazoan fossils and abundant microbial structures in the form of columnar, domal and stratified stromatolites. Other microbially formed structures often seen are peloids, oncoids and microphytolites. Carbonate grainstones and packstones are common in the Krol C and D members and the allochemical constituents are intraclasts, ooids, coated grains, peloids, microbial grains and catagraphs. (Tewari, 2010, 2012; Tewari and Tucker, 2011; Bryanne and Tewari, 2014).

\section{Krol Carbonate Microfacies and Depositional Environment}

The Upper Krol carbonate facies (Krol C, D and E) is a typical Precambrian carbonate. The rock is totally dolomite, the preservation of the fabrics is generally good, and the formation contains abundant microbial structures in the form of stromatolites and grains which are of microbial origin (Figs. 3 and 4).The features of the dolomite described here are interpreted in terms of very early dolomitisation of the sediment, whether it is lime, mud or micritic grains, or of marine cements. Sedimentary structures present in non-stromatolitic Krol carbonates include bird's eyes, mostly on the mm-scale, occurring within peloidal pack/grain-stones and mudstones. Cross laminae and cross bedding are present too, including symmetrical ripples and shallow channel structures. Desiccation cracks locally occur. Shallow-water deposition, with some moderate current activity, accounts for much of the succession, with intermittent periods of exposure. The Upper Krol carbonates are deposited in a peritidal ramp environment (Tewari, 2010, 2012; Tewari and Tucker, 2011). Carbon isotope chemostratigraphy has also confirmed the shallow marine environment compared with other Ediacaran sequences (Tewari, 2010, 2012).

Stromatolites are a very significant feature in the Upper Krol Formation and vary from planar microbial laminites, with desiccation features, laminoid fenestrae, polygonal cracks and intraclasts, to columnar and domal stromatolites on a $10-\mathrm{cm}$ to metre-scale. In addition, there are lime-mudstones, locally with laminae from mechanical deposition of mud, but without microbial lamiae. Carbonate grainstones and packstones are common in the $\mathrm{Krol} \mathrm{C}$ and the grains here are intraclasts, ooids and coated grains, peloids, and microbial grains (Tewari, 2010, Tewari and Tucker, 2011; Bryanne and Tewari, 2014, Figs. 3 and 4). An intertidal to supratidal (shallow water) depositional environment with some moderate currents and intermittent periods of exposure has been suggested for the Upper Krol carbonates of the Lesser Himalaya (Tewari, 2010, 2012). Sedimentary structures present in the non-stromatolitic Krol carbonates include bird's eye structures, cross beddings,

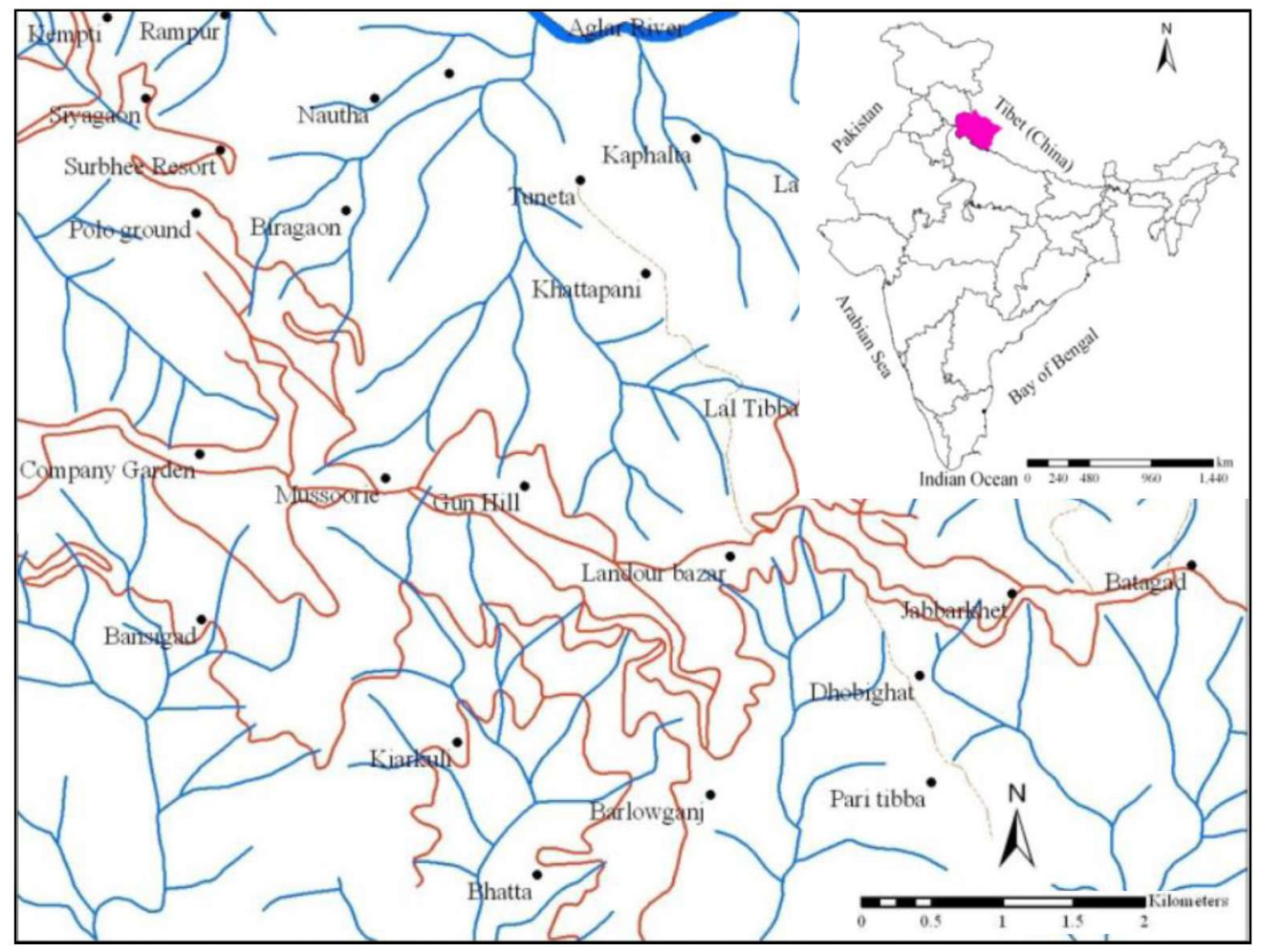

Fig. 2: Map showing drainage and location of Surbhi Resort Landslide 

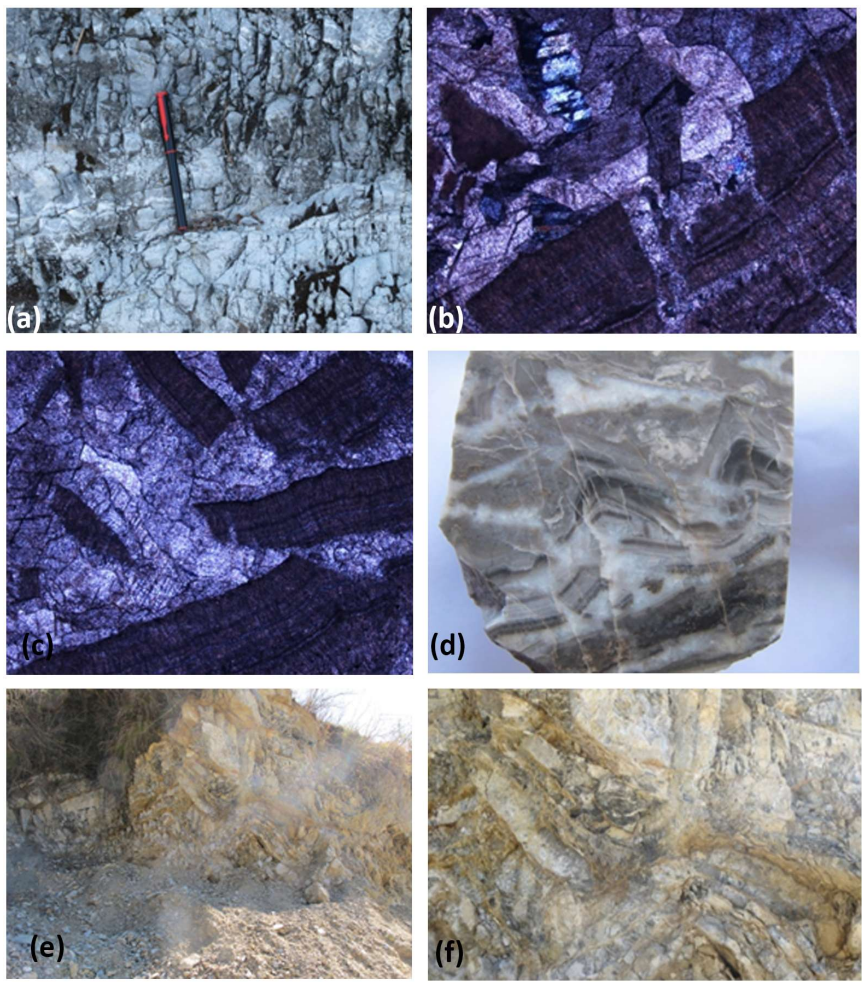

Fig. 3: The highly folded. faulted, deformed and fractured Krol C Limestone on Mussoorie-Kemty road section, Mussoorie syncline: (a) highly fractured and jointed Krol $C$ carbonate, (b) the tectonic desiccation of the limestone, (c) microfaults in brecciated limestone, (d) microfolds and recrystallized calcite veins, (e) folded and sheared limestone, and (f) landslide zone deformation.

symmetrical ripples and shallow channel structures. Mud cracks are also present. Limestone has been severely faulted, folded, deformed and jointed and these structures can be seen on both the limbs of the Mussoorie syncline. Thus, from the macro- to the micro-scale, the tectonic processes and diagenesis are visible in the rocks. The Krol $\mathrm{C}$ limestone appears much more fragile and prone to landslides (Figs. 3, a-f) than the underlying InfraKrol-Blaini-Nagthat or overlying Tal formation with many more observed landslides occurring in this belt.

\section{SURBHI RESORT LANDSLIDE}

The landslide is in total $3.5 \mathrm{~km}$ long, but can be divided into three parts on the basis of the dynamics of the landslide (Bryanne and Tewari, 2014) (Fig. 5):

\section{Zone of Detachment (1650-1325 m amsl)}

It is the crown portion of the landslide as well as the main scarp. It is spoon shaped and is about $400 \mathrm{~m}$ long, $200 \mathrm{~m}$ wide and $30 \mathrm{~m}$ deep. The slope varies from $60-70^{\circ}$. Approximately, $1.25 \times 10^{6} \mathrm{~m}^{3}$ of quaternary deposits have been displaced but it has the potential to displace 5-6 times that
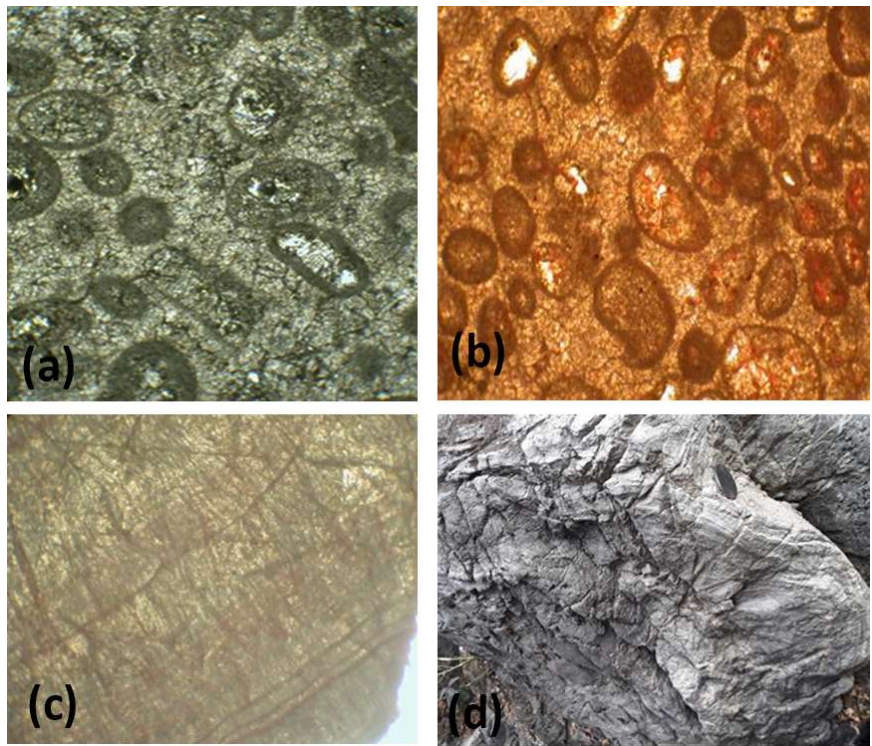

Fig. 4: Photomicrographs of carbonate grains (oolites, intraclasts, coated grains, peloids, microbial grains, microbial laminations and stromatolites showing diagenetic and tectonic imprints. (a) diagenetically replaced oolite and intraclasts, (b) coated grains, peloids, and microbial grains, (c) highly fractured microbial mat laminations, and (d). Stromatolitic limestone in Krol C, Mussoorie area.

volume. Studies during 2005 showed that it is still moving slowly with 4-14 mm/year and models have shown that this portion is the most vulnerable to further sliding (Pal et al., 2010).

\section{Zone of Transportation (1350-1100 m amsl)}

This zone follows the channel of Rangaon-ka-Khala and transports the detached materials from the scarp into the valley below. Since several villages are located here (Rangaon, Nawaridhar, Langwalgaon, Dabla Matela and Biragaon) most damages have been reported from this zone. It is the longest section of the landslide and the angle of the slope varies from $7-70^{\circ}$.

\section{Zone of Accumulation (1100-800 m amsl)}

This zone is at the bottom of the slope and highly inaccessible. Here the slope angle again increases and the debris is remobilized as a debris flow before it finally fills the main valley and runs into the Aglar River.

\section{STRENGTH PARAMETERS}

As can be concluded from the above data (Table 1), the intact lime stone rock pieces are competent and the soil at low moisture levels is cohesive. But unfortunately, due to neotectonic activity, the limestone is highly fractured and joined. This is visible both at macro and micro scales. (Bryanne and Tewari, 2014). This reduces the internal strength of the rocks. The soil 
Table 1: Summery of the strength parameters calculated by different authors for the Surbhi Resort Landslide, Mussoorie Syncline

\begin{tabular}{|c|c|c|}
\hline Strength parameter & Value & Author \\
\hline \multirow[t]{2}{*}{ Sieve analysis } & $30 \%$ clay, $10 \%$ silt, $60 \%$ sand & Bryanne and Tewari, 2014 \\
\hline & $30.9 \%$ fines $($ silt + clay $)$ & Gupta and Ahmed, 2007 \\
\hline \multirow[t]{2}{*}{ In situ moisture content } & $17.72 \%$ (crown portion) & Gupta and Ahmed, 2007 \\
\hline & $7.96 \%$ (toe portion) & \\
\hline \multirow[t]{3}{*}{ Liquid limit } & $26.77 \%$ & Bryanne and Tewari, 2014 \\
\hline & $48 \%$ (crown) & Gupta and Ahmed, 2007 \\
\hline & $17 \%$ (toe) & Gupta and Ahmed, 2007 \\
\hline \multirow[t]{3}{*}{ Cohesion } & $15.7 \mathrm{kN} . \mathrm{m}^{2}$ & Bryanne and Tewari, 2014 \\
\hline & $63.21 \mathrm{kN} / \mathrm{m}^{2}$ & Gupta and Ahmed, 2007 \\
\hline & $84 \mathrm{kN} / \mathrm{m}^{2}$ & Singh et al. 2015 \\
\hline \multirow[t]{3}{*}{ Angle of Internal Friction } & $30.2^{\circ}$ & Bryanne and Tewari, 2014 \\
\hline & $21.96^{\circ}$ & Gupta and Ahmed, 2007 \\
\hline & $47.2^{\circ}$ & Singh et al. 2015 \\
\hline \multirow[t]{4}{*}{ Uniaxial Compression Strength } & $115.71 \mathrm{kPa}($ speed $=1.25 \mathrm{~mm} / \mathrm{min})$ & Bryanne and Tewari, 2014 \\
\hline & $87.18 \mathrm{kPa}($ speed $=1.5 \mathrm{~mm} / \mathrm{min})$ & \\
\hline & $101.264 \mathrm{kPa}($ speed $=2.5 \mathrm{~mm} / \mathrm{min})$ & \\
\hline & $61 \mathrm{MPa}$ & Singh et al. 2015 \\
\hline Point Load Test & $0-25 \mathrm{MPa}$ & Gupta and Ahmed, 2007 \\
\hline Slake Durability Test (intact rocks) & High durability towards weathering & $\begin{array}{l}\text { Bryanne and Tewari, 2014; } \\
\text { Venkateswarlu and Tewari, } 2014\end{array}$ \\
\hline Rock Mass Rating, RMR & Poor quality & Gupta and Ahmed, 2007 \\
\hline Geological Strength Index, GSI & $15-25=$ poor & Gupta and Ahmed, 2007 \\
\hline
\end{tabular}

shows very low permeability, combined with a low liquid limit. Thus, the tertiary overburden fails when the pore pressure increases during the monsoon.

\section{MITIGATION AND BIOENGINEERING}

Since the main trigger is increased pore water pressure, the main focus of the mitigation is on preventing the water from reaching the slope.

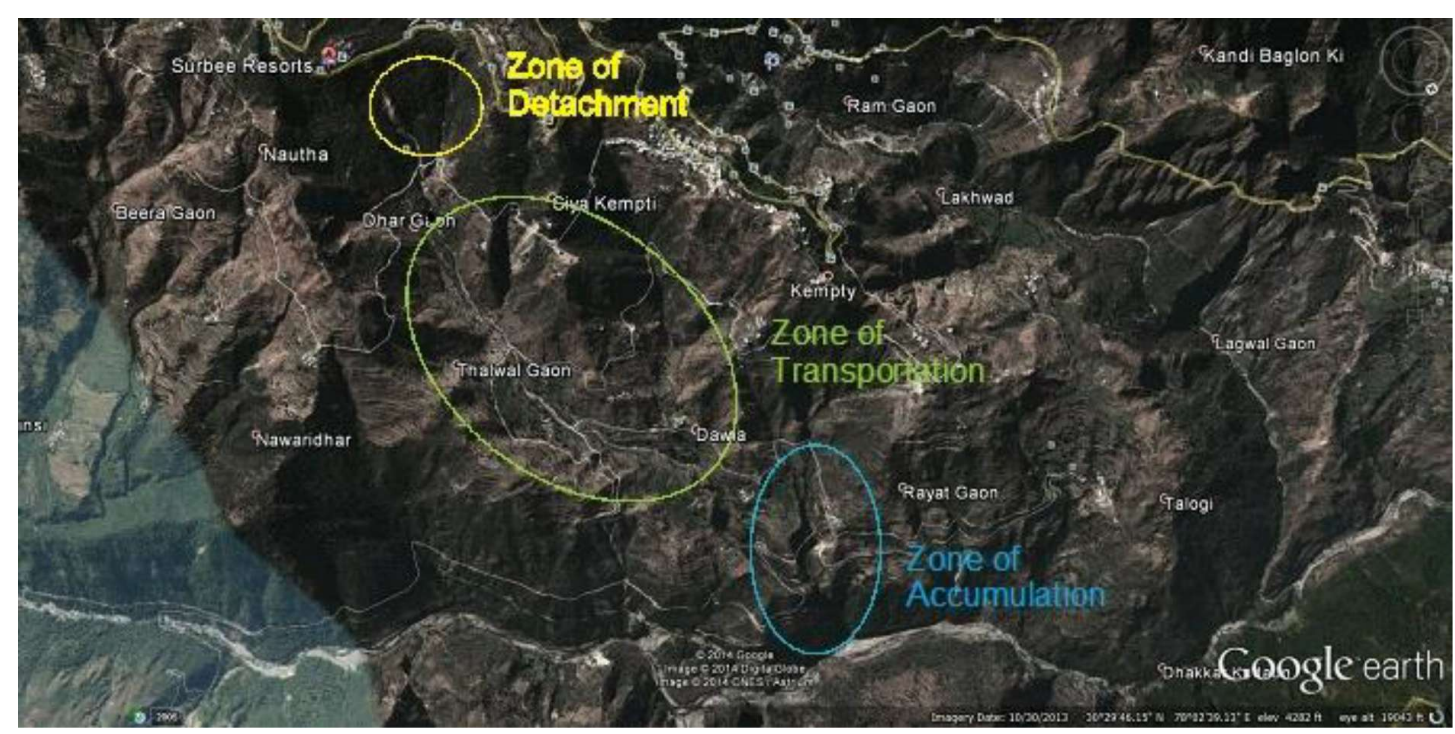

Fig. 5. Google earth map of the Surbhi landslide area showing zones of detachment, transportation and accumulation 
1. First and foremost, all waste water coming from Mussoorie International School and the Polo Ground up slope has to be properly collected and made to run off in the eastern direction. However, this does not seem possible for the waste water from Marriot Hotel, located right on top of Surbhi Resort Landslide. Since this waste water flows onto the slope throughout the year, it extends the duration the slope is saturated and thus increases the risk of landslides.

2. During normal (1-year recurrence) monsoon showers of $100 \mathrm{~mm}$, an estimated $60.000 \mathrm{~m}^{3}$ of water (the catchment area above the Mussoorie-Kempty road is $590,000 \mathrm{~m}^{2}$ ) collects on the Mussoorie-Kempty Road. As it is now, the water flows off the road above the landslide and saturate the slope. Hence to control surface run-off along the road, proper drains, $0.40 \mathrm{~m}$ wide, has to be constructed on the inside of the road. A culvert should be constructed near Siya Gaon to lead the water down a slope which is more stable than the present one.

3. A row of horizontal drains, $0.10 \mathrm{~m}$ in diameter, could be installed at the lower portion of the Zone of Detachment. This will help prevent the ground water to rise up into this zone.

When the flow of water has been accounted for and controlled, it is now possible to arrest the slump taking place within the slope. This can be done with a combination of geotechnical structures and vegetation (bioengineering) to nail the soil to the bed rock.

Vegetation and trees play an important role in stabilizing mountainous terrain. Very few landslides are observed in pristine forests, but on degraded lands gully erosion and landslides are rampant. (Sidle et al., 2006) and Watson et al. (1999). Some of the ways by which trees affect the local climate and slope stability are:

1. Increased evapo-transpiration which lowers the ground water table and the pore water pressure.

2. Trees induce a more moderate rainfall with fewer cloudbursts. During cloudbursts the water droplets hits the ground much harder, creating splash erosion which ultimately leads to gully formation through rill erosion. Also, the rate of infiltration of water reduces during cloudbursts, leading to increased surface run-off which could trigger a debris slide. Further, a more moderate rainfall regime means less possibilities of getting a supersaturated slope.

3. Trees increase the rate of infiltration of rain water into the slope, which is a potential destabilizing factor for the slope, as the pore water pressure increases.

4. The roots of the trees act as suture stitches across the failure plane and effectively bind the soil to the bed rock or stable substrata by their tensile strength. This is especially true to shallow landslides, in which the failure plane is at a depth of less than $5 \mathrm{~m}$. For deep seated landslides, it can be difficult for the roots to penetrate deep enough (Reubens et al., 2007).

5. Some authors are concerned that the weight of the trees might act as a destabilizing factor, as evidenced from block slides in which an entire lump of the slope starts to fail with trees standing intact on the failing block (Simon and Collison, 2002).

\section{Selection of Species}

After the 2008 failure, the vegetation on the Surbhi Resort Landslide has slowly recovered, but this could be assisted by human revegetation of the degraded forest. For a successful reforestation it is important to use local species which are adapted to the local climate and which are useful for the villagers. If the villagers can see the utility of the species, they will be more inclined to take care of the seedlings and prevent grazing of cattle and goats in the area. Some useful species used for reclamation of degraded soils in the Lesser Himalayas are given in Table 2.

\section{Plantation}

One of the problems of natural revegetation is the high slope angle and thin soil cover. It is simply difficult for the seeds to establish themselves without toppling down the slope. The organic matter content of the soil is also low, thus the water holding capacity and concentration of essential nutrients like phosphorous and nitrogen are low (Raina and Gupta, 2009). The following suggestions are made for how to sow the seeds and saplings on the slope (Polster, 2002; Dhital et al., 2013):

1. Benching of the steepest slope to allow the seeds and saplings to perch on. This can be done in several ways. Benches can be cut perpendicularly to the slope and covered with geo-jute. Geo-jute holds the soil in place till the root network has been developed and it decomposes into a fertile mulch which provides nutrients to the rather nutrient poor soil. The saplings and seeds are then planted on top of the geo-jute.

2. Geo-jute has an enormous water holding capacity which means the water stays inside the fibers rather than infiltrating into the ground. Since the surface area is increased, the evaporation from the jute is high further reducing the pore water pressure by returning the water back to the atmosphere.

3. Geo-jute has also been found to be able to drain soils and reduce the water content of the soils.

4. Wattles and fences can be made out of brushwood or bamboo to arrest the downward movement of the top soil. It also prevents rock falls. It gives support and shelter for young saplings to grow up behind on unbenched slopes. When the brushwood structure fails the saplings have grown into a size which can survive on their own. 
Table 2. List of useful plant species used for reclamation of degraded soils in the Lesser Himalaya (after Vasishta et al., 2011)

\begin{tabular}{|c|c|}
\hline Name of species (Common name) & Use \\
\hline \multicolumn{2}{|l|}{ Trees } \\
\hline Quercus leucotricophora (Himalayan oak) & $\begin{array}{l}\text { Dominant species of the forest at this altitude. Used for fuel } \\
\text { and furniture. Is a good soil binder }\end{array}$ \\
\hline Alnus nepalensis (Nepalese alder) & Cricket bats and other light furniture. \\
\hline Toona ciliata (red cedar, toon, toona, Indian mahogany) & Used for fuel and fodder. \\
\hline $\begin{array}{l}\text { Albizia odoratissima (Black siris, kali siris, Ceylon } \\
\text { rosewood) }\end{array}$ & $\begin{array}{l}\text { Binds nitrogen to the soil and makes it available for other } \\
\text { plants }\end{array}$ \\
\hline Cedrus deodara (Deodar) & $\begin{array}{l}\text { Used in Ayurvedic medicine, for essential oils and for timber } \\
\text { for construction. }\end{array}$ \\
\hline Prunus padus (Wild Cherry) & Used for jams and pickles. Birds are attracted to the fruits. \\
\hline Pinus roxburghii (Chir). & Used for timber. \\
\hline \multicolumn{2}{|l|}{ Shrubs } \\
\hline Buddleja asiatica (Butterfly Bush) & Attracts butterflies and birds. \\
\hline Woodfordia fructosa (Dhaula, dhaturgh) & Used for fodder \\
\hline Mimosa himalayana (Alay, Alaru) & Used as fuel wood \\
\hline Rubus ellipticus (golden or yellow Himalayan raspberry) & Medicinal plant \\
\hline Agave sisilana (Rambaansa) & Extremely draught resistant. Grows well on degraded lands. \\
\hline Vitex negundu (Simalu) & Used in Chinese herbal medicine for bronchitis. \\
\hline \multicolumn{2}{|l|}{ Grasses and Bamboo } \\
\hline Cymbopogon martinii, (Palmarosa grass) & $\begin{array}{l}\text { Palmarosa oil has a calming effect on the mind. The grass is } \\
\text { used for deforestation and can grow on poorly drained soils } \\
\text { too. }\end{array}$ \\
\hline Cymbopogon nardus (Java grass) & $\begin{array}{l}\text { Citronella oil is extracted from } C \text {. nardus, which is } \\
\text { extensively used in perfumes and insect repellents. It is a good } \\
\text { soil binder. }\end{array}$ \\
\hline Chrysopogopn fulvus, (Golda grass) & $\begin{array}{l}\text { It is an important fodder species which can be stored as hay. } \\
\text { Good for preventing soil erosion. }\end{array}$ \\
\hline Saccharum spontanum (wild sugarcane, Kans) & $\begin{array}{l}\text { Used in Ayurvedic medicine. The roots can be boiled and } \\
\text { eaten. }\end{array}$ \\
\hline Eriophorum comosum (Hairy cottongrass) & $\begin{array}{l}\text { Grows best on undrained soils in marshes. Used in medicine } \\
\text { for diarrhea. }\end{array}$ \\
\hline Chrysopogon zizanioides (Vetiver grass) & $\begin{array}{l}\text { A grass native to India, can grow upto } 3 \text { meters tall and it } \\
\text { roots penetrate } 4 \text { meters down, it can resist draught, } \\
\text { inundation, fires and grazing. }\end{array}$ \\
\hline Dendrocalamus strictus (Lathi Bans) & $\begin{array}{l}\text { Used for making bamboo articles and for pulp in the paper } \\
\text { industry. Reach 6-18 } \mathrm{m} \text { tall. }\end{array}$ \\
\hline Bambusa bambos (Chova Bans or Giant Thorny Bamboo) & $\begin{array}{l}\text { Another widely used bamboo for scaffolding and building } \\
\text { materials. Can reach } 20-35 \mathrm{~m} \text { tall. }\end{array}$ \\
\hline
\end{tabular}

5. Grasses can be planted in turfs in rows either parallel to the slope or perpendicular. Parallel lines of grass will lead the water faster down the slope, and thus prevent the pore water pressure to build up, but will do nothing to arrest soil erosion. Perpendicular lines of grass are much better suited for arresting surface erosion, but retains the water on the slope. A compromise is lines of turfs slanting on the slope.
6. Most tree species can be planted as saplings on the slope. An exception is Quercus (Himalayan Oak, Fig. 6) which is very difficult to transplant and has to be grown from seeds.

\section{Check dams}

Special attention should be given to the channel of the Rangaon-ka-Khala. Since large amounts of water are flowing 

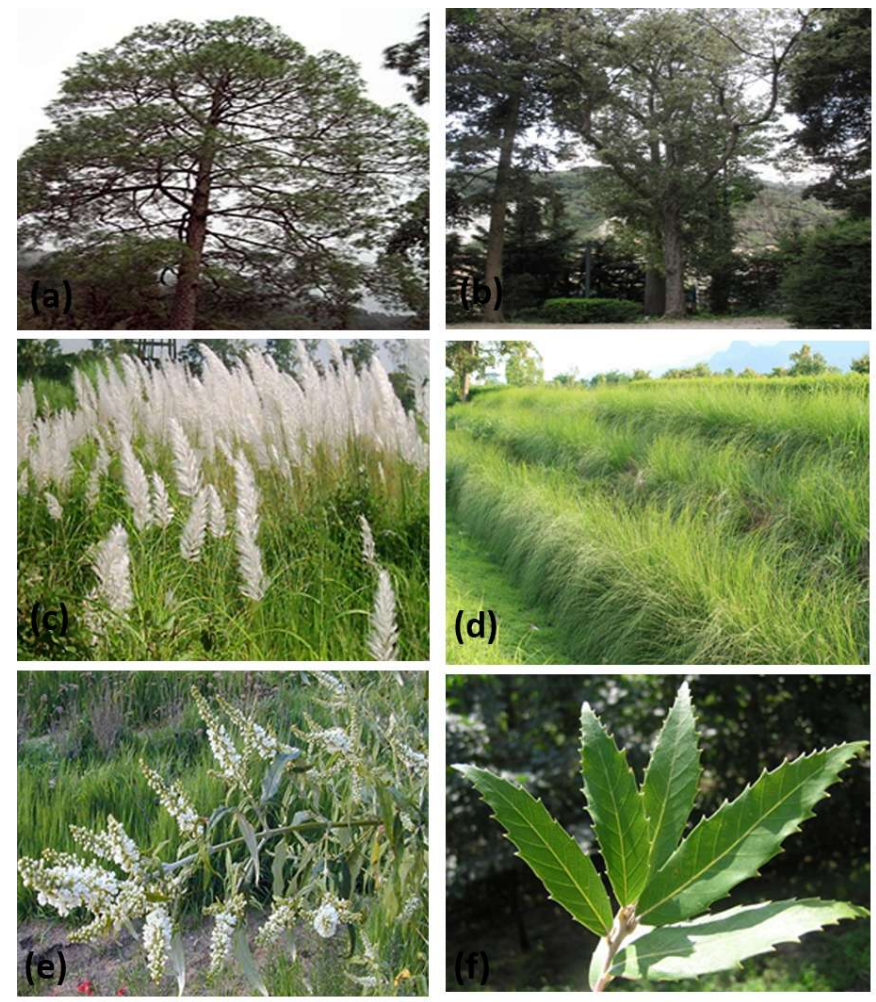

Fig. 6. Trees, shrubs and grasses used for the bioengineering plantation. (a) Pinus roxburghii, (b) Quercus leucotricophora, (c) Saccharum spontanum, kans, (d) Vetiver grass, and (e) Buddleja asiatica, (f) Quercus leucotricophora leaves).

down on near-vertical slopes, the scouring of the banks is very high. This can lead to catastrophic debris slides if left unchecked. The risk of gully formation is also high, hence the banks has to be revegetated with pioneer species, like Dalbergia sisoo (Shisham) or Ipomoea fistula, which can withstand the alternating desiccation and inundation which occur along a seasonal stream like the Rangaon-ka-Khala (Fig. 7). In particular it is important to reduce the discharge by installing check dams throughout the landslide tract. This can be done by constructing gabions out of wire mesh filled with rocks and stones from the slope. They are easy to install and require limited maintenance apart from a general check up on the level of siltation.

However, live check dams constructed out of living Ipomoea fistula stem cuttings and bamboo wattlings are cheaper than mechanical stream bank protection, and in many cases more efficient (Dhital and Tang, 2015). Bamboo species has shown a higher resistance to mechanical stress by water and make excellent retaining structures (Dhital et al., 2013).

\section{EARLY WARNING SYSTEM (EWS)}

For any regional early warning system to be efficient, detailed landslide hazard zonation maps identifying unstable slopes and fragile lithologies are necessary. Such maps are a prerequisite for an efficient disaster management. Several authors
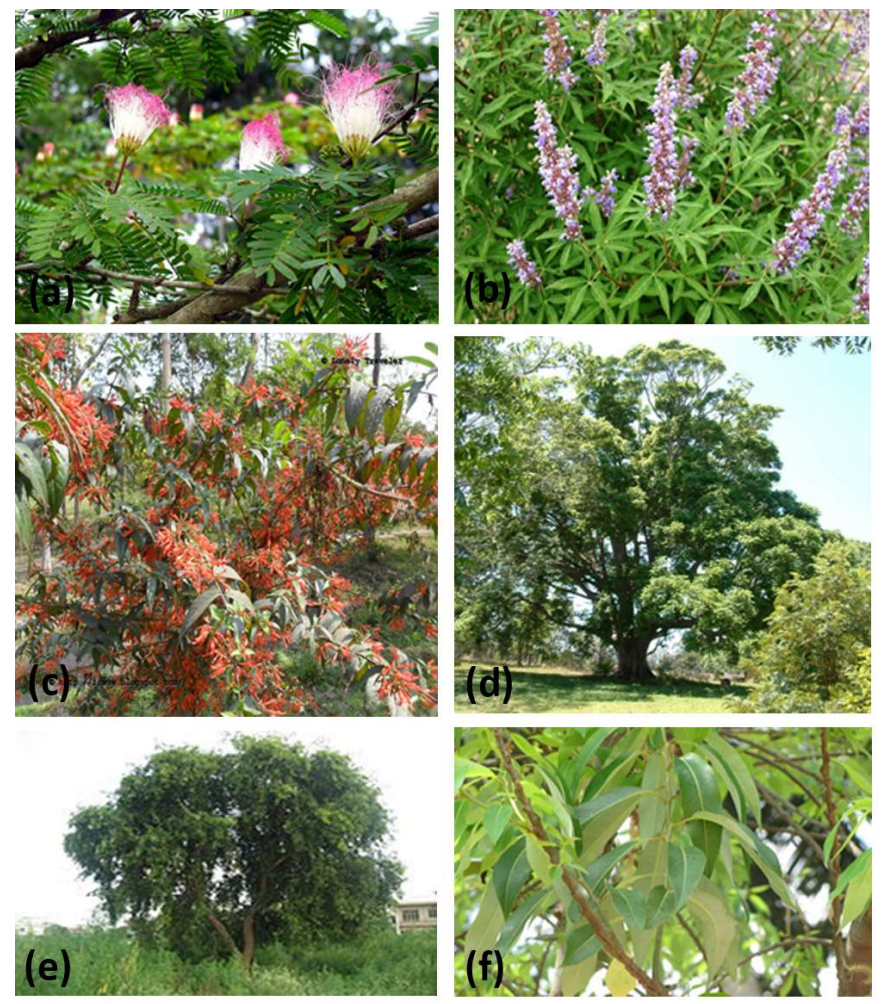

Fig.7 : Plant species generally planted for bioengineering: (a) Mimosa himalaya, (b) Vitex negundu, (c) Woodfordia fruticosa, (d) Toona ciliata, (e) Dalbergia sissoo (Sheesham), (f) Salix tetraasperma

have done efforts in this direction for Uttarakhand including Rautela and Thakur (1999), Saha et al. (2005) Mathew et al. (2009), Rawat et al. (2015), Rout et al. (2015), and Sarkar (2015).

\section{RAINFALL THRESHOLDS}

One thing most of the landslide hazard zonation maps have in common is that they leave out the effect of rainfall, because it is difficult to quantify. However, rainfall data is one of the easiest continuous data to monitor it by local rain gauges and global programs like the satellite based TRMM (Tropical Rainfall Measuring Mission) that makes it attractive for Early Warning Systems.

There have been several attempts at establishing rainfall thresholds that will trigger landslides in the Himalayan region. Mathew et al. (2014) have suggested that intense rainfall of 12 $\mathrm{mm} / \mathrm{h}$ for less than 10 hours or a long-time rainfall for more than 12 hours with intensity of $4 \mathrm{~mm}$ is sufficient to trigger landslide in the Lower Himalaya. Kanungo et al. (2014) was looking into long antecedent rainfall of 10 to 20 days and found that for Chamoli-Joshimath region in the Garhwal Himalaya, $55 \mathrm{~mm}$ of rain in 10 days or $185 \mathrm{~mm}$ rain over a 20-day period is sufficient to trigger landslides. Dahal et al. (2008) found that whenever the daily rainfall crosses $144 \mathrm{~mm}$, there is always a risk of landslides. 
However, these thresholds are insufficient in themselves for an early warning system, unless they are statistically linked to probabilities of a slope failure and a risk assessment like Lagomarsino et al. (2013) did for an early warning system for Emilia Romagna region, Northern Italy. They linked the rainfall thresholds to a probability for the number of landslides in a given region, providing a clear idea for the emergency authorities for what to expect. Recently some initial studies on early warning system has been undertaken in the Sikkim Himalaya, however no results are available. In northeast region of India, SikkimDarjeeling Himalaya are situated in the seismic zone IV and V where earthquakes of great magnitude are occurring and seismogenic landslides are also recorded. A systematic study of landslide both due to heavy rainfall and seismic activity is essentially required for the entire state of Sikkim and Darjeeling hills.

\section{LANDSLIDE WARNING: SUGGESTIONS FOR SURBHI RESORT LANDSLIDE}

After the unstable slopes have been identified and linked with a threshold for when landslides are likely to occur, a warning can then be sent to the District Magistrate, Superintendent of Police, local municipality or Gram Sabha, and major hospitals in the area, preferably indicating where and how many landslides are to be expected. The authorities can then make corresponding precautions like closing vulnerable roads, evacuating villages and life stock, temporarily shutting down hydroelectric power plants and maintaining drains and culverts. For and early warning system for the Surbhi Resort Landslide, it is paramount to monitor the soil moisture by piezometers or by measuring the electrical resistance or dielectric constant. If this is not possible, a general rainfall threshold of $12 \mathrm{~mm} / \mathrm{h}$ for 10 hours or continues rain with $4 \mathrm{~mm} / \mathrm{h}$ for 24 hours has to be used based on the daily weather forecast from IMD's automatic weather station in Mussoorie. Since no work has been done to link statistically the number of landslides in the Garhwal Himalaya to a particular threshold a full-fledged warning cannot be generated yet. There is a need for more detailed data collection with hourly rainfall data for each valley in the region. In case, the Surbhi Resort Landslide reactivates into a fast-moving debris slide, there is a real danger to both Surbhi Resort Hotel, the Marriot Hotel, the villages down slope and their fields and water mills. A proper warning will save lives and property.

\section{CONCLUSION}

The Surbhi Resort Landslide has been the focus of extensive studies for the last 25 years with numerous authors attempting to describe the area from its geological, geotechnical, lithological and socio-economic perspectives. The Krol C limestone in which the landslide is located, is a highly sheared, fractures, brecciated and deformed limestone. The limestone is characterized by chert breccia, intraclasts, oolites, coated grains, peloids, microbial grains, microbial laminae and mostly stratified and domal stromatolites. These features suggest that it was deposited in a shallow marine environment mainly in inter tidal to subtidal region. The limestone is also folded and faulted and tectonic and diagenetic imprints at microscopic stage has been observed. The intact rocks and soils exhibit high strength parameters, but due to shearing, folding, faulting, jointing by tectonic activity, the shear strength decreases drastically to the point of slope failure. This is accentuated by the reduction in cohesion as the pore water pressure increases during the monsoon. The present detailed study suggests several means of mitigating the continuous slump by using minor engineering structures like benching of the slope and drains along the MussoorieKempty road. Major emphasis is however on bioengineering of the slope and natural channel Rangaon-ka-Khala. Here it is necessary to do a proper revegetation and reforestation of the slope by planting local species like Quercus (Oak), Pinus (Pine), Cedrus (Cypress), Alnus (Alder), and Prunus (Plum). Shrubs useful for reclamation of degraded lands are pioneer species like Dalbergia sisoo (Shisham), Agave, Buddleja asiatica (Butterfly Bush) and Mimosa himalayana (Alay, Alaru) and grasses and bamboos like Cymbopogon martinii, (Palmarosa grass), Chrysopogon zizanioides (Vetiver grass), Cymbopogon nardus (Java grass) Dendrocalamus strictus (Lathi Bans) and Bambusa bambos (Giant Thorny Bamboo). Since the slope has been found to be unstable for more than 20 years, a continuous monitoring of the landslide with the aim of developing an early warning system would be appropriate. Different authors have done preliminary steps like attempting to define various rainfall thresholds that trigger landslides in Garhwal Himalaya and creating detailed Landslide Hazard Zonation maps. However, no efforts have so far been done in trying to predict how many and where different landslides might occur under given circumstances, neither in a probabilistic nor deterministic manner. In conclusion, in the absence of above initiatives, the slope is likely to fall again which will affect the livelihood of the villagers living downslope of Surbhi Resort Landslide negatively if not detrimentally.

\section{ACKNOWLEDGEMENTS}

The present work was done in the National Geotechnical Facility (NGF, DST Project), during the tenure of Professor V.C. Tewari as Project Director in 2013. Authors are thankful to former Director of Wadia Institute of Himalayan Geology for providing laboratory facilities in both NGF and WIHG. Victoria Bryanne studied the Surbhi landslide for her M.Sc. dissertation. Figures 8 and 9 have been reproduced from the earlier paper by Bryanne, V.Z. and Tewari, V.C. (2014) with permission from the Executive Editor ,Indian Geological Congress, Roorkee, India. We are thankful to the anonymous reviewer for critical review and constructive comments for improvement of the paper. Dr. A.K. Misra, Head of the Geology Department of Sikkim University is thanked for the discussions. We are thankful to anonymous reviewer for positive comments to improve the paper. 


\section{REFERENCES}

Bryanne, V.Z. and Tewari, V.C., 2014, Geotechnical and geological investigations of the Surbhi Resort Landslide, Mussoorie syncline, Uttarakhand Lesser Himalaya. Jour. Indian Geol. Cong., v. 6 (2), pp. 57-77.

Dahal, R.K. and Hasegawa, S., 2008, Representative rainfall thresholds for landslides in the Nepal Himalaya. Geomorphology, v.100, pp.429-443. DOI 10.1016/j.geomorph.2008.01.014.

Dhital, Y.P., Kayastha, R.B., and Shi, J., 2013., Soil Bioengineering Application and Practices in Nepal. Environmental Management, v. 51, pp. 354-364. DOI: 10.1007/s00267-012-0003-7

Dhital, Y.P. and Tang, Q., 2015, Soil bioengineering application for flood hazard minimization in the foothills of Siwaliks, Nepal. Ecol. Engn., v. 74, pp. 458-462. DOI: 10.1016/j.ecoleng.2014.11.020.

Gupta, V. and Ahmed, I., 2007, Geotechnical Characteristics of Surabhi Resort Landslide in Mussoorie, Garhwal Himalaya, India. Jour. of Him. Geol., v. 28 (2), pp. 21-32.

Gupta, V., Bhasin, R.K., Kaynia, A.M., Kumar, V., Saini, A.S., Tandon, R.S., and Pabst, T., 2016, Finite element analysis of failed slope by shear strength reduction technique: a case study for Surabhi Resort Landslide, Mussoorie Towhnship, Garhwal Himalaya. Geomatics, Nat. Hazards and Risks, v. 7 (5), pp. 1677-1690. DOI: 10.1080/19475705.2015.1102778.

Kanungo, D.P. and Sharma, S., 2014, Rainfall thresholds for prediction of shallow landslides around Chamoli-Joshimath region, Garhwal Himalayas, India. Landslides, v. 11, pp. 629-638. DOI: 10.1007/s10346-013-0438-9.

Khanduri, S., 2017, Landslide Hazard around Mussoorie: The Lesser Himalayan Tourist Destination of Uttarakhand, India Jour. Geogr. Nat. Disast., v. 7. 200p. DOI: 10.4172/2167-0587.1000200

Mathew, J., Babu, D.G., Kundu, S., Kumar, K.V., and Pant, C.C., 2014, Integrating intensity-duration based rainfall threshold and antecedent rainfall-based probability estimate towards generating early warning for rainfall-induced landslides in parts of the Garhwal Himalaya, India. Landslides, v. 11 (4), pp. 575-588. DOI: 10.1007/s10346013-0408-2.

Mathew, J., Jha, V.K., and Rawat, G.S., 2009, Landslide susceptibility zonation mapping and its validation in part of Garhwal Lesser Himalaya, India, using binary logistic regression analysis and receiver operating characteristic curve method. Landslides, v. 6(1), pp.17-26. DOI: 10.1007/s10346-008-0138-z.

Pal, S., Kaynia, A., Bhasin, R., and Paul, D., 2010, Distinct Element Stability Analysis of Surbhee Resort Landslide in Garhwal Himalayas, India. http://eqrisk.info/pdf/paper_NIDM_Shilpa_2009_02.pdf
Polster, D.F., 2002, Soil bioengineering techniques for riparian restoration. Proceedings of the 26th Annual British Columbia Mine Reclamation Symposium in Dawson Creek, BC, pp. 230-239.

Raina, A.K. and Gupta, M.K., 2009, Soil and vegetation studies in relation to parent material of Garhwal Himalayas, Uttarakhand (India). Ann. For., v. 17 (1), pp.71-82.

Rautela, P. and Thakur, V.C. 1999. Landslide Hazard Zonation in Kaliganga and Madhyamaheshwar valleys of Garhwal Himalaya: A GIS based approach. Journal of Himalayan Geology, v. 20(2), pp. 31-44.

Rawat, M. S., Uniyal. D.P., Dobhal, R., Joshi., V., Rawat, B.S., Bartwal, A., Singh, D., and Aswal, A. 2015, Study of landslide hazard zonation in Mandakini Valley, Rudraprayag district, Uttarakhand, using remote sensing and GIS. Current Science, v.109(1), pp.158-170.

Reubens, B., Poesen, J., Danjon, F., Geudens, G., and Muys, B., 2007, The role of fine and coarse roots in shallow slope stability and soi erosion control with a focus on root system architecture: a review. Trees, v. 21, pp. 385-402. DOI: $10.1007 / \mathrm{s} 00468-007-0132-4$.

Rout, M.M., Das, J.K., and Das, R., 2015, Probabilistic seismic hazard assessment of NW and Central Himalayas and the adjoining region. Journal Earth System. Science, v.124 (3), pp. 577-586. DOI: 10.1007/s12040-015-0565-x.

Saha, A., Gupta, R., Sarkar, I., Arora, M.C., and Saplovics, E., 2005, An approach for GIS-based statistical landslide susceptibility zonation with a case study in the Himalayas. Landslides. v. 2, pp. 61-69. DOI: 10.1007/s10346-0040039-8.

Sarkar, S., Kanungo, D.P., and Sharma, S., 2015, Landslide hazard assessment in the Upper Alaknanda Valley of Indian Himalayas. Jour. Geom., Nat. Haz. and Risk., v. 6(4), pp. 308-325. DOI: 10.1080/19475705.2013.847501.

Sidle, R., Ziegler, A., Negishi, J., Nik, A., Siew, R., and Turkelboom, F., 2006, Erosion processes in steep terrain - Truths, myths and uncertainties related to forest management in Southeast Asia. Forest Ecol. and Management, v. 224, pp.199-225. https://doi.org/10.1016/j.foreco.2005.12.019

Simon, A. and Collison, A., 2002, Quantifying the mechanical and hydrologic effects of riparian vegetation on streambank stability. Earth surface processes and landforms, v. 27, pp. 527-546. DOI: 10.1002/esp.325.

Singh, M., Pandit, K., and Shaunik, D., 2015, Some aspects of geotechnical investigations at Surbee Landslide, Mussoorie. In; Conference paper of 50th Indian Geotechnical Conference, 17-19 December, 2015, Pune, India.

Tewari, V. C. ,2010, Terminal Neoproterozoic (Ediacaran) Chemostratography of the Lesser Himalaya, India. Jour. Ind. Geol. Cong., v. 2, pp. 69-93.

Tewari, V. C. 2012, Neoproterozoic Blaini Glacial Diamictite 
and Ediacaran Krol Carbonate Sedimentation in the Lesser Himalaya, India. Geol. Soc., London, Special Publication 19. DOI: $10.1144 / \mathrm{SP} 366.3$.

Tewari, V.C. 2013a, Interview in Nature (Tubingen, Germany in 28th Himalaya- Karakorum- Tibet Workshop), v. 501, pp.14, 5th September.

Tewari, V.C., 2013b, Himalayan Tsunami: Devastating Natural Disaster in the Uttarakhand Himalaya (Key Note Address). 28thÊHimalayan Karakorum Tibet Workshop and 6thÊInternational Symposium on Tibetan Plateau Joint Conference, Tübingen/Germany, 22-24 August 2013.

Tewari, V.C. 2014b, Recent natural disaster in the Uttarakhand Himalaya and future geotechnical remedial measures. Jour. Geol. Soc. India, v. 84(1), pp. 125-126.
Tewari, V.C. and Tucker, M. 2011, Ediacaran Krol Carbonates of the Lesser Himalaya, India: Stromatolitic Facies, Depositional Environment and Diagenesis. In: V. C.Tewari, and J. Seckback (Eds.), Stromatolites: Interaction of Microbes with Sediments. Dordrecht: Springer Verlag, pp. 135-156. https://doi.org/10.1007/978-94-007-03971 - 7

Venkateswarlu, B. and Tewari, V.C., 2014, Characterization of Strength and Durability Indices of Highly Fractured Krol Limestone near Surabhi Landslide, Mussoorie-Kempty Link Road. In : Innovative Practices in Rock Mechanics, Bangaluru, pp. 329-336.

Watson, A., Phillips, C., and Marden, M., 2002, Root strength, growth and rates of decay: root reinforcement changes of two tree species and their contribution to slope stability. Plant and Soil, v. 217, pp. 39-47. 
